Zeszyty Naukowe Szkoły Głównej Gospodarstwa Wiejskiego w Warszawie

Problemy Rolnictwa Światowego tom 18 (XXXIII), zeszyt 2, 2018: 342-352

DOI: $10.22630 /$ PRS.2018.18.2.61

Katarzyna Żmija ${ }^{1}$

Uniwersytet Ekonomiczny w Krakowie

\title{
Determinanty i perspektywy prowadzenia działalności rolniczej w małych gospodarstwach rolnych z pozarolniczą działalnością gospodarczą
}

\section{Determinants and Prospects of Conducting Agricultural Activities in Small Farms with Non-Agricultural Activities}

\begin{abstract}
Synopsis. Celem opracowania jest identyfikacja czynników wynikających z prowadzenia działalności pozarolniczej w małych gospodarstwach rolnych oraz zbadanie ich wpływu na prowadzona w nich rolniczą działalność produkcyjną. Poznanie tych prawidłowości umożliwi świadome stymulowanie ze strony państwa małych gospodarstw w celu rozwijania działalności pozarolniczej, która zapewni im dodatkowe, a często wiodące źródło dochodów. Zaprezentowano wyniki własnych badań ankietowych przeprowadzonych wśród osób posiadających małe gospodarstwa rolne, prowadzących równocześnie działalność rolniczą i pozarolniczą. Wyniki badań wykazały, iż w większości przypadków prowadzona działalność pozarolnicza pozwala na bardziej efektywne wykorzystanie zasobów gospodarstwa rolnego dzięki możliwości zastosowania ich również na potrzeby prowadzenia działalności pozarolniczej. Charakter wpływu działalności pozarolniczej na działalność rolniczą zależy jednak w dużym stopniu od jej rodzaju i stopnia powiązania z gospodarstwem rolnym.
\end{abstract}

Slowa kluczowe: działalność pozarolnicza, pozarolnicza gospodarka wiejska, małe gospodarstwa rolne, rolnictwo

\begin{abstract}
The aim of the study is to identify factors resulting from non-agricultural activities in small farms and to examine their impact on the agricultural production carried out in these farms. Understanding these processes will help the state develop a way to encourage these small farms to develop non-agricultural activities, which will provide them with an additional, and often primary, source of income. The results of the authors' surveys conducted among farmers possessing small farms, conducting both agricultural and non-agricultural activities, are presented. The research results showed that in most cases, non-agricultural activities can allow farm resources to be used more efficiently. However, the nature of the impact of non-agricultural activities on agricultural activities depends on the type of activities, and on their level of connection with the agricultural holding.
\end{abstract}

Key words: non-agricultural activities, non-farm rural economy, small farms, agriculture

JEL Classification: Q1, Q12, Q18

\section{Wprowadzenie}

Współcześnie uznaje się, iż zasadniczym warunkiem rozwoju podmiotów funkcjonujących na rynku, w tym również gospodarstw rolnych, jest ich elastyczność

\footnotetext{
${ }^{1}$ dr, Katedra Ekonomiki i Organizacji Przedsiębiorstw, ul. Rakowicka 27, 31-510 Kraków, e-mail: zmijak@uek.krakow.pl; https://orcid.org/0000-0002-4119-8012

Publikacja została sfinansowana ze środków przyznanych Wydziałowi Zarządzania Uniwersytetu Ekonomicznego w Krakowie, w ramach dotacji na utrzymanie potencjału badawczego.
} 
i umiejętność dokonywania zmian. Gospodarstwa rolnicze podlegaja, podobnie jak przedsiębiorstwa, procesom ewolucji i w różny sposób oraz w różnym stopniu dostosowują się do wymogów otoczenia zewnętrznego. Podmioty, które nie są w stanie sprostać wymogom otoczenia, przestają się rozwijać, popadają $\mathrm{w}$ stagnację, a w skrajnych przypadkach ulegają likwidacji (Kołoszko-Chomentowska i Sieczko, 2014; Wojewodzic, 2010). W gospodarstwach posiadających zdolność do wprowadzania zmian dokonywane są dostosowania, bądź to poprzez wprowadzanie zmian w zakresie prowadzonej działalności rolniczej lub też poprzez dywersyfikację źródeł dochodów rolnika i jego rodziny na skutek podjęcia pracy zarobkowej poza gospodarstwem lub rozwoju działalności pozarolniczej (Grochowska, 2015; Kassie i in., 2017; Żmija, 2016).

Pozarolnicza działalność gospodarcza stanowi ważny element funkcjonowania gospodarstw rolnych, zarówno w Polsce, jak i w całej Unii Europejskiej (Komisja Europejska, 2008; Parlament Europejski, 2016). Badania prowadzone przez różnych autorów wskazują, iż w Polsce ma ona szczególne znaczenie ekonomiczne dla małych obszarowo gospodarstw (Augustyńska-Grzymek, 2013; Błąd, 2015; Kisiel i Jarzębowicz, 2017; Krakowiak-Bal, 2009; Zioło i Badach, 2013). Jej uruchomienie może wywierać różnokierunkowy wpływ na działalność gospodarstwa rolnego. $\mathrm{Z}$ jednej strony stanowić może czynnik jego rozwoju, w wielu jednak przypadkach, zwłaszcza w odniesieniu do gospodarstw rolnych cechujących się małym areałem i niskimi dochodami z produkcji rolniczej, stanowić może element restrukturyzacji gospodarstwa, prowadzącej do zmian w sferze organizacji działalności produkcyjnej i realokacji jego zasobów, skutkującej marginalizacją znaczenia działalności rolniczej. W kontekście sytuacji małych gospodarstw rolnych $\mathrm{w}$ Polsce wskazane ścieżki zmian uznać należy za pożądane, gdyż ich konsekwencją będzie utrzymanie się na rynku gospodarstw cechujących się największą żywotnością ekonomiczną przy równoczesnym eliminowaniu z rynku gospodarstw niedochodowych. Zaznaczyć należy, iż w przypadku małych, rodzinnych gospodarstw procesy recesywne dokonujące się $\mathrm{w}$ nich przyjmuja bardziej ewolucyjny charakter i polegają na stopniowym wycofywaniu się z poszczególnych działalności i przenoszeniu posiadanych zasobów czynników produkcji do innych form aktywności gospodarczej. Upadek ekonomiczny w drobnych, dwuzawodowych gospodarstwach rolnych przebiega inaczej niż $\mathrm{w}$ przypadku podmiotów funkcjonujących $\mathrm{w}$ sektorze małych $\mathrm{i}$ średnich przedsiębiorstw. Jest zwykle procesem dłuższym, bardziej rozłożonym w czasie z uwagi na specyficzne role, które one pełnią (Musiał, 2009; Tudor, 2015).

\section{Mikroekonomiczny aspekt powiązań pomiędzy działalnością rolniczą i pozarolniczą}

Rodzinne gospodarstwo rolne jest specyficznym podmiotem gospodarki spajającym w jedność gospodarstwo domowe rolnika i gospodarstwo produkcyjne. Gospodarstwo domowe udostępnia gospodarstwu produkcyjnemu zasoby czynników produkcji, w zamian oczekuje dochodu rolniczego, który może przyjąć formę naturalną (produkty rolnicze) albo pieniężną. Oznacza to, iż zasoby, którymi dysponuje rodzina w postaci ziemi, kapitału czy siły roboczej stanowią własność zarówno gospodarstwa domowego, jak i jednostki produkcyjnej jaką jest gospodarstwo rolne (Wojewodzic, 2010). W przypadku uruchomienia działalności pozarolniczej można mówić o triadzie podmiotów spajanych osobą rolnika. Są to gospodarstwo domowe, gospodarstwo rolne i nowo powstały organizm 
gospodarczy prowadzący działalność pozarolniczą. W sytuacji tej, nowo powstały podmiot pozarolniczy (przedsiębiorstwo pozarolnicze) ma wspólnego właściciela z gospodarstwem rolnym i wspólnie z nim korzysta z zasobów czynników produkcji gospodarstwa domowego.

U podstaw decyzji o podjęciu działalności pozarolniczej mogą leżeć różne przesłanki. W literaturze przedmiotu wyróżnia się dwie grupy czynników skłaniających rolników do tego rodzaju decyzji (tabela 1). Są to czynniki wypychające, tzw. push factors (związane przede wszystkim z koniecznością pozyskania środków finansowych na utrzymanie i wynikające z niewystarczalności gospodarstwa rolnego jako jedynego źródła dochodów) i czynniki przyciagające tzw. pull factors (związane przede wszystkim z chęcią samorealizacji i podejmowania nowych wyzwań, a także atrakcyjnością biznesu pozarolniczego, przejawiającą się przykładowo większą rentownością lub mniejszym ryzykiem działalności) (Mishra, 2005).

Tabela 1. Przykładowe czynniki przyczyniające się do dywersyfikacji działalności w kierunku działalności pozarolniczej

Table 1. Examples of factors contributing to the diversification of activities towards non-agricultural activities

\begin{tabular}{l|l}
\hline \multicolumn{1}{c|}{ Czynniki wypychające (push factors) } & \multicolumn{1}{c}{ Czynniki przyciągające (pull factors) } \\
\hline $\begin{array}{l}\text { rosnący niedobór gruntów ornych i zmniejszanie się } \\
\text { dostępu do żyznych gruntów, }\end{array}$ & $-\begin{array}{l}\text { większa opłacalność pracy i inwestycji w sektorach } \\
\text { pozarolniczych, }\end{array}$ \\
- spadek produktywności gospodarstw rolnych, & $-\begin{array}{l}\text { niższe ryzyko działalności pozarolniczej } \\
\text { w porównaniu z działalnością w gospodarstwie, }\end{array}$ \\
- malejące zyski z rolnictwa, & $-\begin{array}{l}\text { generowanie stabilnych dochodów, } \\
\text { zaspokajających potrzeby gospodarstwa domowego } \\
- \text { zmniejszenie bazy zasobów naturalnych, } \\
- \text { aktualne wydarzenia i szoki (wstrząsy), } \\
\text { atrakcyjnego w szczególności dla młodych ludzi }\end{array}$ \\
$\begin{array}{l}\text { ograniczenie lub brak dostępu do kapitału } \\
\text { finansowego. }\end{array}$ & \\
\hline
\end{tabular}

Źródło: opracowanie własne na podstawie: Davies, 2006; Mishra, 2005.

Uruchomienie dodatkowej, pozarolniczej działalności może stanowić czynnik rozwoju dla prowadzonej działalności rolniczej, zwłaszcza w sytuacji gdy jest efektem realizacji strategii dywersyfikacji horyzontalnej lub wertykalnej (Żmija, 2016). W wyniku prowadzenia działalności pozarolniczej rolnicy mogą uzyskiwać rozmaite korzyści, wśród których wymienić należy (Ostromęcki i in., 2015; Sikorska-Wolak, 2011; Zając, 2009):

- wzrost dochodów rodziny uzyskiwanych dzięki dodatkowej aktywności gospodarczej,

- poprawę stopnia wykorzystania posiadanych zasobów (pracy, kapitału, ziemi),

-zdobywanie niezbędnej wiedzy, doświadczenia i know how, czyli poprawę jakości kapitału ludzkiego, który stanowi obecnie zasadniczy czynnik rozwoju zarówno działalności rolniczej, jak i pozarolniczej,

- możliwość przejmowania części wartości dodanej wytworzonej w rolnictwie dzięki prowadzonej działalności pozarolniczej,

- możliwości ograniczenia ryzyka gospodarowania, wynikającego np. z uwarunkowań naturalnych lub rynkowych.

Pojawienie się znacznych dysproporcji w opłacalności pomiędzy prowadzonymi w gospodarstwie działalnościami (rolniczą i pozarolniczą) powodować jednak może również negatywne konsekwencje. Wpływ działalności pozarolniczej na rolniczą jest pozytywny lub neutralny do momentu, dopóki prowadzona jest ona w oparciu o wolne 
zasoby gospodarstwa domowego. Po ich wykorzystaniu następować będzie o nie konkurencja, co przy niskiej opłacalności działalności rolniczej skutkować może dywestycjami w gospodarstwie rolnym, polegającymi na ekstensyfikacji, ograniczeniu lub zaniechaniu produkcji rolnej i/lub wycofywaniu zasobów $\mathrm{z}$ działalności rolniczej. Uwolnione $\mathrm{w}$ ten sposób zasoby mogą być przy tym angażowane $\mathrm{w}$ prowadzoną działalność pozarolniczą (Bogusz i Wojewodzic, 2012; Kuiper i in., 2007; Sroka i Wojewodzic, 2010). Wpływ działalności pozarolniczej na działalność rolniczą może mieć zatem różnoraki charakter, sprzyjając jej utrzymaniu lub rozwijaniu, dzięki dodatkowym dochodom lub możliwościom wykreowanym z działalności pozarolniczej. Powodować może również negatywne implikacje dla trwałości gospodarstwa rolnego w sytuacji występowania znaczących dysproporcji w opłacalności obu działalności i/lub konkurowania o wolne zasoby produkcyjne.

\section{Dane i metody}

Celem opracowania jest identyfikacja czynników wpływających na działalność rolniczą w związku z prowadzeniem przez rolnika posiadającego małe gospodarstwo rolne działalności pozarolniczej, a także skutków oddziaływania działalności pozarolniczej na działalność rolniczą w okresie bieżącym i w dłuższym horyzoncie czasowym. Poznanie prawidłowości zachodzących w małych gospodarstwach rolniczych w tym zakresie jest zagadnieniem interesującym zarówno z teoretycznego, jak i praktycznego punktu widzenia. Pozwala na diagnozowanie tych procesów, a tym samym świadome oddziaływanie na te podmioty za pomocą instrumentów stosowanych w ramach polityki gospodarczej państwa.

Rozważania teoretyczne na temat zależności występujących pomiędzy działalnością rolniczą i pozarolniczą wzbogacone zostały o wyniki własnych badań ankietowych przeprowadzonych w 2015 roku wśród osób posiadających małe gospodarstwa rolne, realizujących ścieżkę dywersyfikacji źródeł swoich dochodów poprzez równoczesne prowadzenie działalności rolniczej i pozarolniczej. Badaniami objęto 80 rolników z województwa małopolskiego posiadających gospodarstwa rolne o powierzchni od 1 do 5 ha użytków rolnych. Dobór próby przebiegał w dwóch etapach. W pierwszym etapie wylosowano grupę 301 rolników korzystających z płatności bezpośrednich, ich dobór miał charakter losowy. W kolejnym kroku z grupy tej wybrano wszystkich rolników prowadzących pozarolniczą działalność gospodarczą. Zakwalifikowano ich do dalszych etapów badań. Respondenci pochodzili z 41 gmin, zlokalizowanych na obszarze 14 powiatów województwa małopolskiego, charakteryzujących się zróżnicowanym poziomem rozwoju przedsiębiorczości.

\section{Wyniki badań}

Analiza cech społecznych respondentów wykazała, iż większą skłonność do angażowania się w pozarolniczą działalność gospodarczą przejawiają stosunkowo dobrze wykształceni mężczyźni (wykształcenie średnie lub wyższe), w średnim wieku (30 - 50 lat). Ponad połowa badanych posiadała ponadto wykształcenie rolnicze. Respondenci dysponowali zróżnicowanym areałem ziemi - prawie 59\% ankietowanych stanowili właściciele gospodarstw o powierzchni powyżej 4 ha do 5 ha UR, jedna piąta badanych 
posiadała gospodarstwa o powierzchni powyżej 3 do 4 ha użytków rolnych, 11,0\% powyżej 2 do 3 ha, a 10\% rolników gospodarowało na użytkach o powierzchni 1 do 2 ha. Wszyscy badani prowadzili produkcję roślinną. Wśród dominujących upraw, tj. takich, które mają największe znaczenie ekonomiczne w gospodarstwie rolnym, wymieniane były najczęściej zboża, ale także uprawy specjalistyczne: warzywa gruntowe i uprawy pod osłonami. Prowadzona produkcja roślinna miała przeważnie charakter towarowy. Równocześnie jedynie nieco ponad $11,0 \%$ badanych gospodarstw prowadziło produkcję zwierzęca, najczęściej utrzymując trzodę chlewną.

Obok działalności rolniczej respondenci prowadzili również działalność pozarolnicza rejestrowaną ( $91,2 \%$ badanych) lub nierejestrowaną (agroturystyka, 8,8\% badanych). Wśród rodzajów prowadzonej działalności dominowały usługi $(67,5 \%)$, przede wszystkim w zakresie budownictwa, rolnictwa czy agroturystyki. Zdecydowanie rzadziej prowadzona była działalność handlowa, głównie w zakresie sprzedaży hurtowej owoców i warzyw lub produkcyjna (przetwórstwo spożywcze, produkcja wyrobów z metalu, produkcja mebli). Przedsiębiorcy - rolnicy charakteryzowali się zróżnicowanym stażem prowadzenia tej działalności, dla $81,2 \%$ badanych wynosił on jednak dłużej niż 2 lata. Ponad trzy czwarte respondentów rozpoczęło działalność pozarolniczą w 2004 roku i w latach następnych. Aż $52,5 \%$ respondentów nie zatrudniało pracowników na potrzeby prowadzonej działalności pozarolniczej, co wskazuje, iż miała ona najczęściej formę samozatrudnienia. Była to też działalność najczęściej o zasięgu lokalnym lub regionalnym. Jedynie 16,2\% badanych jako rynek swojego działania wskazało obszar całego kraju.

Istotnym elementem wiążącym rolniczą sferę działalności rolników ze sferą pozarolniczą jest wykorzystanie zasobów gospodarstwa rolnego lub własnych produktów rolnych do prowadzenia działalności pozarolniczej. Na fakt ten wpływa możliwość zwiększenia dochodu rolnika poprzez większe zaktywizowanie niewykorzystanych dotychczas w pełni w działalności rolniczej wolnych zasobów czynników produkcji, a także możliwość poszukiwania lepszych, efektywniejszych zastosowań dla tych zasobów, które wykorzystywane są w działalności rolniczej, nie dają jednak zadawalających efektów ekonomicznych. Jak wykazały badania autora prowadzone na tej samej grupie respondentów, prezentowane w innych publikacjach, w przypadku większości rolników u podstaw decyzji o uruchomieniu dodatkowej działalności o charakterze pozarolniczym leżały przede wszystkim motywy finansowe, związane z pozyskaniem alternatywnego źródła dochodów. Istotnym czynnikiem była jednak również możliwość lepszego wykorzystania zasobów gospodarstwa rolnego (ziemi, pracy, kapitału rzeczowego i finansowego oraz własnych produktów rolnych), decydująca często również o wyborze branży (Żmija, 2016; 2017). Wyniki przeprowadzonych badań wskazują, że w badanej próbie zasoby gospodarstwa rolnego były wykorzystywane na potrzeby prowadzenia działalności pozarolniczej przez 71,3\% rolników (tabela 2). Zaznaczyć należy, iż w grupie tej znalazły się osoby prowadzące działalność pozarolniczą w branżach, które są:

- rozszerzeniem dotychczasowej działalności o produkty lub usługi pokrewne, pozostające $\mathrm{w}$ związku $\mathrm{z}$ dotychczasową działalnością rolniczą (np. usługi na rzecz rolnictwa z wykorzystaniem własnego sprzętu),

- rozszerzeniem działalności gospodarstwa o działania poprzedzające lub następujące po dotychczas realizowanym procesie produkcji rolniczej (np. przetwórstwo rolnospożywcze lub sprzedaż bezpośrednia własnych produktów rolnych), 
- niepowiązane $\mathrm{z}$ dotychczas prowadzoną działalnością rolniczą, bazują jednak na zasobach gospodarstwa rolnego (np. działalność w zakresie zakwaterowania i gastronomii, w tym agroturystyka).

W grupie osób nie korzystających z zasobów gospodarstwa rolnego na potrzeby prowadzonej działalności pozarolniczej $(28,7 \%$ badanych) znalazły się natomiast osoby prowadzące działalność gospodarczą niezwiązaną z gospodarstwem rolnym, najczęściej polegającą na świadczeniu różnego rodzaju usług budowlanych, produkcji mebli, doradztwie technicznym czy produkcji artykułów spożywczych, nieopartej jednak na przetwarzaniu własnych produktów z gospodarstwa rolnego.

Do zasobów wykorzystywanych na potrzeby prowadzonej działalności pozarolniczej zaliczano najczęściej własne produkty gospodarstwa rolnego, budynki, zarówno mieszkalne, jak i gospodarcze, posiadany przez gospodarstwo rolne park maszynowy, nieco rzadziej zasoby ziemi. Do najrzadziej wykorzystywanych zasobów gospodarstwa rolnego należały natomiast siła robocza zatrudniona w gospodarstwie rolnym oraz inwentarz żywy i zasoby finansowe pochodzące $\mathrm{z}$ działalności rolniczej.

Tabela 2. Wykorzystanie zasobów gospodarstwa rolnego w działalności pozarolniczej

Table 2. Utilization of farm resources in non-agricultural activities

\begin{tabular}{l|cc}
\hline \multicolumn{1}{c|}{ Wyszczególnienie } & $\begin{array}{c}\text { Liczba rolników } \\
\text { wykorzystujących } \\
\text { zasoby [N=80] }\end{array}$ & $\begin{array}{c}\text { Odsetek rolników } \\
\text { wykorzystujących } \\
\text { zasoby [\%] }\end{array}$ \\
\hline $\begin{array}{l}\text { Rolnicy wykorzystujący zasoby gospodarstwa rolnego dla } \\
\text { potrzeb prowadzenia pozarolniczej działalności, w tym } \\
\text { wykorzystujący*: }\end{array}$ & 57 & 71,3 \\
$\begin{array}{l}\text { własne produkty gospodarstwa rolnego } \\
\text { budynki }\end{array}$ & 29 & 36,3 \\
park maszynowy (maszyny, urządzenia) & 25 & 31,3 \\
zasoby ziemi & 23 & 28,8 \\
zasoby siły roboczej (członkowie rodziny, pracownicy & 16 & 20,0 \\
najemni) & 7 & 8,8 \\
inwentarz żywy & 1 & 1,3 \\
zasoby finansowe & 1,3 \\
\hline
\end{tabular}

* badani mogli wskazać więcej niż jeden rodzaj zasobów.

Źródło: opracowanie własne na podstawie przeprowadzonych badań.

Analizując wyniki badań uznać można, iż w większości przypadków prowadzona działalność pozarolnicza pozwala na bardziej efektywne wykorzystanie zasobów gospodarstwa rolnego dzięki możliwości zastosowania ich również na potrzeby prowadzenia działalności pozarolniczej. Przede wszystkim korzyść ta dotyczy produktów wytwarzanych w gospodarstwie (dzięki czemu staje się możliwe zwiększenie wartości dodanej poprzez ich przetwarzanie, sprzedaż lub wykorzystanie np. w działalności związanej z zakwaterowaniem i gastronomia) oraz budynków i parku maszynowego stanowiących zaplecze techniczne gospodarstwa.

W opinii badanych prowadzenie działalności pozarolniczej przynosi korzyści nie tyle dla samego gospodarstwa rolnego, co przede wszystkim dla rodziny rolnika. Wszyscy rolnicy jako zasadniczą korzyść wskazywali uzyskanie alternatywnego źródła dochodów 
dla rodziny (tabela 3). Zaznaczyć należy, iż w 2015 roku w badanej grupie dla 32,5\% rolników udział dochodów z działalności pozarolniczej w ogólnej kwocie dochodów gospodarstwa domowego nie przekraczał $20 \%$, w przypadku $28,7 \%$ badanych mieścił się on w przedziale $20-50 \%$, natomiast dla $38,8 \%$ badanych źródło to stanowiło ponad $50 \%$ dochodów rodziny. Oznacza to, iż łącznie dla $61,2 \%$ badanych pozarolnicza działalność stanowiła dodatkowe źródło dochodu, a dla pozostałych 38,8\% źródło głównego dochodu (Żmija, 2016).

Inną istotną korzyścią z prowadzenia działalności pozarolniczej jest fakt, iż stanowi ona miejsce pracy dla członków rodziny rolnika. Na korzyść tę wskazało 15,0\% respondentów. Badania wykazały równocześnie, iż zasoby przeznaczone na realizację działalności pozarolniczej tylko w pojedynczych przypadkach wykorzystywane są w gospodarstwie rolnym (9,0\% ogółu badanych). Sytuacja taka dotyczyła przede wszystkim majątku rzeczowego (sprzętu, maszyn i urządzeń) kupowanego na potrzeby prowadzonej działalności pozarolniczej. Jedynie 7,5\% respondentów wskazało na występowanie transferu wiedzy, kompetencji, umiejętności np. z zakresu zarządzania działalnością, finansów, marketingu, umiejętności przedsiębiorczych, nawiązywania kontaktów, podpisywania umów itp. I wykorzystywanie ich również w prowadzonej działalności rolniczej. Dochody z działalności pozarolniczej nie były również w większości przypadków przeznaczane na finansowanie działalności bieżącej lub inwestycyjnej gospodarstwa rolnego.

Tabela 3. Korzyści dla gospodarstwa rolnego i rodziny płynące z działalności pozarolniczej

Table 3. Benefits for the farm and family from non-agricultural activities

\begin{tabular}{l|cc}
\hline \multicolumn{1}{c|}{ Korzyści } & $\begin{array}{c}\text { Liczba rolników } \\
\text { wskazujących daną } \\
\text { korzyść [N=80] }\end{array}$ & $\begin{array}{c}\text { Odsetek rolników } \\
\text { wskazujących daną } \\
\text { korzyść [\%] }\end{array}$ \\
\hline $\begin{array}{l}\text { dodatkowe dochody dla rodziny } \\
\text { miejsce pracy dla członków rodziny }\end{array}$ & 80 & 100,0 \\
$\begin{array}{l}\text { wykorzystywanie w gospodarstwie rolnym majątku (sprzętu, } \\
\text { maszyn, urządzeń) kupowanego na potrzeby prowadzonej } \\
\text { działalności pozarolniczej }\end{array}$ & 12 & 15,0 \\
$\begin{array}{l}\text { nabycie nowej wiedzy, kompetencji, umiejętności } \\
\text { wykorzystywanych również w działalności rolniczej } \\
\text { finansowanie bieżących wydatków na działalność rolniczą } \\
\text { dochodami z działalności pozarolniczej } \\
\begin{array}{l}\text { finansowanie wydatków inwestycyjnych na działalność rolniczą } \\
\text { dochodami z działalności pozarolniczej }\end{array}\end{array}$ & 7 \\
\hline
\end{tabular}

Źródło: opracowanie własne na podstawie przeprowadzonych badań.

Analiza zmian, jakie w latach 2004-2015 wystapiły we wszystkich badanych gospodarstwach rolnych wykazała szereg pozytywnych zjawisk wskazujących na rozwój działalności rolniczej (tabela 4). Interesującym faktem jest, iż zdecydowanie częściej pozytywne zmiany $\mathrm{w}$ swoich gospodarstwach rolnych wprowadzali ci rolnicy, którzy prowadzą działalność z nim powiązaną, tj. wykorzystują zasoby gospodarstwa rolnego w swojej działalności pozarolniczej. Częściej dokonywali oni zwiększenia skali prowadzonej działalności rolniczej poprzez powiększenie powierzchni upraw lub pogłowia zwierząt. Zdecydowanie częściej zatrudniali oni nowych pracowników w swoim 
gospodarstwie rolnym. Wykorzystanie zasobów gospodarstwa częściej przekładało się również na wzrost udziału produkcji przeznaczanej na rynek i dochodów uzyskiwanych z działalności rolniczej. Można zatem wnioskować, iż prowadzenie działalności bazującej na zasobach gospodarstwa rolnego jest czynnikiem częściej stymulującym pozytywne zmiany w samym gospodarstwie rolnym niż działalność z nim nie związana.

Tabela 4. Odsetek rolników, którzy odnotowali w latach 2004-2015 zmiany w swoim gospodarstwie rolnym Table 4. Percentage of farmers who noted changes in their farms from 2004-2015

\begin{tabular}{l|ccc}
\hline Zmiany w gospodarstwie rolnym w latach 2004-2015 & $\begin{array}{c}\text { Odsetek } \\
\text { rolników } \\
\text { ogółem } \\
{[\mathrm{N}=80]}\end{array}$ & $\begin{array}{c}\text { Odsetek } \\
\text { korzystających } \\
\text { z zasobów } \\
\text { gospodarstwa } \\
\text { rolnego [N=57] }\end{array}$ & $\begin{array}{c}\text { Odsetek } \\
\text { niekorzystających } \\
\text { z zasobów } \\
\text { gospodarstwa } \\
\text { rolnego [N=23] }\end{array}$ \\
\hline zwiększenie powierzchni upraw & 55,0 & 70,2 & 17,4 \\
zwiększenie pogłowia zwierząt & 3,8 & 5,3 & 0,0 \\
zwiększenie zatrudnienia & 11,3 & 14,0 & 4,3 \\
zwiększenie udziału produkcji przeznaczanej na rynek & 67,5 & 71,9 & 56,5 \\
wzrost dochodów z działalności rolniczej & 78,8 & 89,5 & 52,2 \\
\hline
\end{tabular}

Źródło: opracowanie własne na podstawie przeprowadzonych badań.

Na pytanie o negatywny wpływ działalności pozarolniczej na gospodarstwo rolne większość badanych odpowiedziała, iż nie wpływa ona negatywnie na gospodarstwo rolne (tabela 5). Odpowiedzi takiej udzielali znacznie częściej rolnicy prowadzący działalność powiązaną z gospodarstwem rolnym bądź to branżowo i/lub poprzez wykorzystanie w niej jego zasobów. Negatywny wpływ działalności pozarolniczej na gospodarstwo rolne wskazywały natomiast relatywnie częściej te osoby, które prowadziły działalność w ogóle niepowiązaną z nim. Wpływ ten polegał przede wszystkim na niepodejmowaniu nowych inwestycji - tak zadeklarowały prawie wszystkie osoby wskazujące na występowanie negatywnych konsekwencji działalności pozarolniczej. W pojedynczych przypadkach wskazywano na zmniejszenie produkcji pod wpływem działalności pozarolniczej lub sprzedaż ziemi. Prowadzenie działalności pozarolniczej nie skłaniało natomiast rolników do wyzbywania się innych składników majątku, takich jak np. sprzęt czy maszyny rolnicze.

Tabela 5. Czy wystapił negatywny wpływ na gospodarstwo rolne? (\% odpowiedzi)

Table 5. Has there been a negative impact on the agricultural holding? (\% answers)

\begin{tabular}{l|cc}
\multicolumn{1}{c|}{ Wyszczególnienie } & TAK & NIE \\
\hline Ogółem badani, w tym: & 30,0 & 70,0 \\
- prowadzący działalność powiązaną & 15,8 & 84,2 \\
z gospodarstwem rolnym & & 34,8 \\
- prowadzący działalność niepowiązaną & 65,2 & \\
z gospodarstwem rolnym & & \\
\hline
\end{tabular}

Źródło: opracowanie własne na podstawie przeprowadzonych badań.

Dla zbadania perspektywicznego wpływu działalności pozarolniczej na działalność rolniczą przeanalizowano plany rolników, odnoszące się do ich działalności. Jak wynika 
z uzyskanych odpowiedzi, zaprezentowanych $\mathrm{w}$ tabeli 6 , jedna czwarta badanych rolników planuje w przyszłości zaprzestać prowadzenia działalności rolniczej. Wśród argumentów, które podaja jako powód takiej decyzji, pojawia się przede wszystkim fakt, iż prowadzą oni równolegle pozarolniczą działalność gospodarczą i wolą skoncentrować się na jej rozwoju. Wśród innych argumentów przemawiających za taką decyzją wymieniano fakt posiadania zbyt małego gospodarstwa o za małej skali produkcji, aby opłacało się w nie inwestować. Wśród osób, które prezentują takie plany trzy czwarte prowadzi działalność niezwiązaną $\mathrm{z}$ gospodarstwem rolnym.

Tabela 6. Plany rolników odnośnie przyszłości działalności rolniczej

Table 6. Plans of farmers regarding the future of agricultural activity

\begin{tabular}{l|ccc}
\hline \multicolumn{1}{c|}{ Plany rolników na przyszłość } & $\begin{array}{c}\text { Odsetek } \\
\text { rolników } \\
\text { ogółem } \\
{[\%],} \\
\text { w tym: }\end{array}$ & $\begin{array}{c}\text { - prowadzacy } \\
\text { działalność } \\
\text { powiązaną } \\
\text { z gospodarstwem } \\
\text { rolnym [\%] }\end{array}$ & $\begin{array}{c}\text { - prowadzący } \\
\text { działalność } \\
\text { niepowiązaną } \\
\text { zospodarstwem } \\
\text { rolnym [\%] }\end{array}$ \\
\hline Zaprzestanie działalności rolniczej & 25,0 & 6,2 & 18,8 \\
Równoległe prowadzenie obu działalności, z tego: & 75,0 & 65,0 & 10,0 \\
- utrzymanie produkcji rolnej na dotychczasowym poziomie & 28,8 & 20,0 & 8,8 \\
- zwiększenie produkcji rolnej & 46,2 & 45,0 & 1,2 \\
\hline
\end{tabular}

Źródło: opracowanie własne na podstawie przeprowadzonych badań.

Pozostałe $75,0 \%$ rolników wyraziło chęć równoległego rozwijania obu rodzajów działalności. W grupie tej zdecydowaną większość stanowią rolnicy prowadzący działalność pozarolniczą związaną z gospodarstwem rolnym - stanowią oni $65,0 \%$ ogółu badanych. Ponad jedna czwarta, tj. 28,8\% respondentów zamierza w przyszłości utrzymać produkcję rolną na dotychczasowym poziomie uznając, iż jest ona aktualnie dostosowana do możliwości gospodarstwa. Jako jeden $\mathrm{z}$ argumentów niezwiększania produkcji w gospodarstwie rolnym pojawia się również powód związany $\mathrm{z}$ prowadzeniem działalności pozarolniczej, która uzupełnia dochody gospodarstwa domowego rolnika. Prawie połowa badanych planuje natomiast $\mathrm{w}$ najbliższych latach zwiększyć produkcje rolną. Powodem tego w przeważającej mierze jest fakt, iż rolnicy ci prowadzą działalność pozarolniczą związaną z gospodarstwem rolnym lub rolnictwem i mogą na potrzeby tej działalności wykorzystywać produkty wytwarzane w gospodarstwie rolnym lub korzystać $\mathrm{z}$ jego zaplecza technicznego.

\section{Podsumowanie}

Przeprowadzone badania wpisują się $\mathrm{w}$ nurt badań związanych $\mathrm{z}$ analizą zależności pomiędzy działalnością rolniczą i pozarolniczą w małych gospodarstwach rolnych. Wyniki przeprowadzonych badań skłaniają do sformułowania następujących wniosków.

1. Pozarolnicza działalność gospodarcza postrzegana jest przez rolników jako źródło korzyści przede wszystkim dla samej rodziny rolnika. Korzyści te są utożsamiane przez rolników z możliwością wygenerowania dodatkowych dochodów dla rodziny, bądź też powstaniem miejsca pracy dla członków rodziny rolnika. 
2. Istotną korzyścią mocno eksponowaną przez rolników jest możliwość wykorzystania w działalności pozarolniczej zasobów gospodarstwa rolnego, co umożliwia zwiększenie efektywności ich wykorzystania.

3. W toku prowadzonych badań stwierdzono, że o ile zasoby gospodarstwa rolnego są często wykorzystywane w działalności pozarolniczej, o tyle sytuacja odwrotna, tj. wykorzystywanie zasobów pozarolniczych w działalności rolniczej, występuje stosunkowo rzadko i dotyczy przede wszystkim parku maszynowego.

4. W prawie co trzecim badanym gospodarstwie rolnym działalność pozarolnicza implikuje negatywne konsekwencje przede wszystkim w postaci zaniechania lub ograniczenia inwestycji rzeczowych lub też (zdecydowanie rzadziej) zmniejszenia produkcji lub sprzedaży ziemi. Sytuacja ta dotyczy głównie tych rolników, którzy prowadzą działalność pozarolniczą w ogóle nie powiązaną z gospodarstwem rolnym. W gospodarstwach tych następować zatem będzie najprawdopodobniej stopniowa marginalizacja działalności rolniczej, co potwierdzają również wypowiedzi samych rolników na temat przyszłości działalności rolniczej prowadzonej w ich gospodarstwie.

5. Dla zdecydowanej większości badanych pozarolnicza działalności stanowi uzupełniające względem rolnictwa źródło dochodów i nie planują oni zaniechania działalności rolniczej w najbliższej przyszłości. Czynnikiem sprzyjającym takiej decyzji jest fakt prowadzenia działalności pozarolniczej powiązanej z gospodarstwem rolnym i wykorzystywania w niej jego zasobów. W przypadku takich rolników pozarolnicza działalność sprzyja pozytywnym zmianom w gospodarstwie rolnym stając się istotnym czynnikiem zapewniającym jego trwałość, a nawet rozwój.

\section{Literatura}

Augustyńska-Grzymek, I. (2013). Małe ekonomicznie gospodarstwa rolne w regionie Mazowsze i Podlasie możliwości ich przetrwania (Farms of small economic size in the Mazowsze and Podlasie region - the chances of their survival). Problemy Drobnych Gospodarstw Rolnych, 2, 5-23.

Błąd, M. (2015). Pluriactivity of farming families - old phenomenon in new times. Pobrane 22.05.2018 z http://ageconsearch.umn.edu/bitstream/139799/2/vol.\%207_12.pdf.

Bogusz, M., Wojewodzic, T. (2012). Agroturystyka - od dywersyfikacji do repozycjonowania działalności gospodarstwa rolnego (Agritourism - from diversification to repositioning of agricultural farm activities). Zeszyty Naukowe Uniwersytetu Szczecińskiego Ekonomiczne Problemy Ustug, 86, 211-221.

Davies, J. (2006). Rural non-farm livelihoods in transition economies: emerging issues and policies, electronic Journal of Agricultural and Development Economics, 3(2), 180-224.

Grochowska, R. (2015). Polish experience from the transformation period and the EU membership, future, challenges and strategies for small farm holders. Pobrane 20.04.2018 z http://www.fao.org/fileadmin/ user_upload /reu/europe/documents/Events 2015 /fcss/pol_en.pdf.

Kassie, G.W., Kim, S., Fellizar, F.P. Jr. (2017). Determinant factors of livelihood diversification: Evidence from Ethiopia. Cogent Social Sciences, 3, 1-16.

Kisiel, R., Jarzębowicz, N. (2017). Non-agricultural business activity in the Olecko District. Journal of Agribusiness and Rural Development, 4(46), 787-794.

Kołoszko-Chomentowska, Z., Sieczko, L. (2014). Gospodarstwo rolne jako podmiot w gospodarce narodowej (Agricultural farm as an entity in the national economy). Ekonomia i Zarzqdzanie, 6(1), 97-111.

Komisja Europejska. (2008). Other gainful activities: pluriactivity and farm diversification in EU-27. Brussels: European Commission. Directorate General for Agriculture and Rural Development.

Krakowiak-Bal, A. (2009). Pozarolnicza działalność gospodarcza polskich gospodarstwach rolniczych na tle gospodarstw z krajów UE (Other gainful activity in agricultural holdings in Poland and EU countries). Infrastruktura i Ekologia Terenów Wiejskich, 5, 209-217.

Kuiper, M., Meijerink, G., Eaton, D. (2007). Rural Livelihoods: Interplay Between Farm Activities, Non-Farm Activities and the Resource Base. W: R.P. Roetter, H. Van Keulen, M. Kuiper, J. Verhagen, H.H. Van Laar 


\section{K. Żmija}

(red.) Science for Agriculture and Rural Development in Low-income Countries, Dordrecht: Springer, $77-$ 95.

Mishra, A. (2005). Entrepreneurial motivation in start-up and survival of micro- and small enterprises in the rural non-farm economy. Journal of Small Business and Entrepreneurship, 3, 289-326.

Musiał, W. (2009). Rozważania nad upadłością gospodarstw rodzinnych w Polsce (Reflections on the bankruptcy of family farms in Poland). Wieś $i$ Rolnictwo, 1 (142), 44-61.

Ostromęcki, A., Zając, D., Mantaj, A. (2015). The importance of non-agricultural economic activity of farmers in the modernization process of farms. Acta Sci. Pol., Oeconomia, 14 (4), 83-92.

Parlament Europejski. (2016). Farm diversification in the EU. Pobrane 22.05.2018 z: http://www.europarl.europa. eu/RegData/etudes/BRIE/2016/581978/EPRS_BRI(2016)581978_EN.pdf.

Sikorska-Wolak, I. (2011). Dywersyfikacja ekonomiczna gospodarstw rolnych jako przejaw przedsiębiorczych zachowań rolników (Economic diversification of farms as a manifestation of entrepreneurial behavior of farmers). Zeszyty Naukowe SGGW Ekonomika i Organizacja Gospodarki Żywnościowej, 9, 29-42.

Sroka, W., Wojewodzic, T. (2010). Agroturystyka - panaceum na problemy rolnictwa (Agritourism - a panacea for agriculture problems). Problemy Zagospodarowania Ziem Górskich, 57, 31-39.

Tudor, M. 2015. Small scale agriculture as a resilient system in rural Romania. Studies in Agricultural Economics, $117,27-34$.

Wojewodzic, T. (2010). Dywestycje w gospodarstwach rolnych - istota, definicje, podział (Divestitions in farms essence, definitions, division). Wieś $i$ Rolnictwo, 2, 96-108.

Zając, D. (2009). Korzyści i bariery współpracy rolników - przedsiębiorców z otoczeniem instytucjonalnym (Benefits and barriers for cooperation between farmers-entrepreneurs and institutional environment). Zagadnienia Ekonomiki Rolnej, 320(3), 50-64.

Zioło, M., Badach, E. (2013). Pozarolnicza działalność gospodarcza w Polsce na tle krajów Unii Europejskiej (Non-Agricultural Business Activity in Poland in Comparison with Other European Union Countries). Roczniki Naukowe Stowarzyszenia Ekonomistów Rolnictwa i Agrobiznesu, 15(5), 394-400.

Żmija, D. (2016). Wpływ wspólnej polityki rolnej Unii Europejskiej na funkcjonowanie małych gospodarstw rolnych w Polsce (The impact of the common agricultural policy of the European Union on the functioning of small farms in Poland). Warszawa: Difin.

Żmija, K. (2017). Microeconomic factors of the development of enterprises as perceived by rural entrepreneurs of the Małopolskie Province. Acta Scientiarum Polonorum. Oeconomia, 16(1), 111-120.

Żmija, K. (2016). Strategie różnicowania działalności gospodarczej przez rolników posiadających drobne gospodarstwa rolne (Strategies for business activities diversification implemented by farmers possessing small farms). Roczniki Naukowe Stowarzyszenia Ekonomistów Rolnictwa i Agrobiznesu, 18(3), 419-425.

Do cytowania / For citation:

Żmija K. (2018). Determinanty i perspektywy prowadzenia działalności rolniczej w małych gospodarstwach rolnych z pozarolniczą działalnością gospodarczą. Problemy Rolnictwa Światowego, 18(2), 342-352; DOI: 10.22630/PRS.2018.18.2.61

Żmija K. (2018). Determinants and Prospects of Conducting Agricultural Activities in Small Farms with Non-Agricultural Activities (in Polish). Problems of World Agriculture, 18(2),342-352;

DOI: $10.22630 /$ PRS.2018.18.2.61 